\title{
ROLE OF TRIBAL VANA SAMRAKSHANA SAMITHI (VSS) MEMBERS IN BUILDING FOREST PROTECTION AND ECO-TOURISM AT VAZHACHAL ECO-TOURISM AREA IN THRISSUR DISTRICT OF KERALA
}

\author{
Dr.Antony J Kuttencherry \\ ICSSR Post Doctoral Fellow \\ Department of Applied Economics \\ Cochin University of Science and Technology \\ (CUSAT) \\ Kochi-682022, Kerala
}

\author{
Dr.P Arunachalam \\ Professor\& Head \\ Department of Applied Economics \\ Cochin University of Science and Technology \\ (CUSAT) \\ Kochi-682022, Kerala
}

Article DOI: https://doi.org/10.36713/epra5469

\begin{abstract}
Tribal communities are mainly living nearby the forest areas and their life routine and activities are connected with the forest. Majority of the tribals depend upon forest for their livelihood. The tribals know the characteristic of forest and forest teaches the tribals how to live and move in forest. The 1988 National Forest Policy envisaged Joint Forest Management (JFM) also known as Community Forest Management (CFM), which means forest protection with the support of forest dependent communities. The participatory forestry management (PFM) defines the protection of the forest, manage the noon-wood resources with the support of local people and ensure the livelihood income for local people. The one of the aims of the participatory Forest Management (PFM) is the welfare of the tribals and build the livelihood mission among the tribals. Vana Samrakshana Samithi (VSS) is also known as village level body and it is functioning under the Participatory Forest Management (PFM). The people living nearby the forests are joined in Vana Samrakshana Samithi (VSS) and with their support, forest department manages various activities related to forest protection. The Vana Samrakshana Samithi (VSS) has a great role in improving environmental protection and the concept of eco-tourism. They get livelihood income and also social interaction trainings by the activities of VSS. The VSS activities have supported the tribals by ensuring the livelihood income and in social trainings. The involvement of the tribals through the VSS, makes them aware of the environmental protection, eco-tourism concept, and forest protection among the society. The paper attempts to study the role of tribal members of Vana Samrakshana Samithi (VSS), how to engage in environmental protection, forest protection and building the eco-tourism concept in Vazhachal waterfalls eco-tourism area in Thrissur District of Kerala.
\end{abstract}

KEY WORDS: VSS, Eco-Tourism, Forest Protection, Environmental Protection and Tribals

\section{INTRODUCTION}

The first forest Act was enacted in 1865 in India and the definition of Forest was "the land covered with tree, brushwood and jungle". The trees were cut for the need of railway, defence and construction works. Massive deforestation activities were held before and after Independence of India. The 1988 National Forest Policy gave more importance to ensuring the forest protection areas. The Act ensured that forest area shall cover minimum 33 percentages of the total geographical land area. Community Forest Management (CFM) was one of the contributions of the 1988 National Forest Policy. Encouraging the forest protection has been in the hands of forest dependent community. Forest Dependent communities are mainly tribal communities and they are settled inside the forest 
or nearby the forest. One of the major income sources of tribals is collection of Non-Timber Forest Produce (NTFP) and selling it to non-tribals. The roots, leaves, wax, honey and herbs these are very essentials for making ayurvedic medicines.

\section{Vana Samrakshana Samithi (VSS)}

One of the major outcomes of 1988 National Forest Policy was introduction of the participatory Forest Management (PFM). Forest protection has been with the support of forest depending communities and ensuring livelihood income for forest nearby living people and forest depending people. The majority of forest depending communities are tribals. The forest depending communities had been alienated from using the product of forest. This was resulted in deforestation, poaching, degradation other illegal and harmful action in forest. The community Forest Management (CFM) is the one of the best movement for the protection of the forest with the support of local community. Preserving, conserving and protecting the wildlife, giving more powers and responsibilities to local communities without disturbing the flora and fauna. In Kerala Joint Forest Management Council (JFMC) at village level are known as Vana Samrakshana Samthi (VSS). The Samithis' are functioned under the Forest Development Agency (FDA). The Forest Development Agency is registered under the Tranvancore-Cochin Charitable Societies Registration Act of 1955 and it is controlled and managed by the Kerala Forest Department. The major works of the VSS members are harvesting forest produce, prevention of fire, theft and damage, illegal activities, grazing, reporting forest offence to the forest department, assisting the forest officials and in distribution of return from forestry operations (Kerala State Planning Board,2014). The Vana Samrakshana Samithi (VSS) members get livelihood income and gone under the social trainings.

\section{Eco-Tourism}

Eco-tourism is a kind tourism, which defines the minimal the impact upon the environment, ecological sustainability, and avoid the negative impacts of new modern tourism. The international Eco-tourism Society (TIES) defines eco-tourism as: "responsible travel that conserves the environment and sustains the well being of local people". Eco-tourism or responsible tourism concept involve four major pillars, which are (a) minimising environmental impact, (b) respecting host cultural, (c) maximum benefit to local people and (d) maximum tourist satisfaction. The study (Sangchumnong, 2018) stated that eco-tourism has balanced the flow of international travels with the impact of local destination empowerment. Which is raised the conservation activities and sustainable tourism. Participatory Forest Management (PFM) has a vital role in the promotion of the eco-tourism. The Vana Samrakshana Samithi (VSS) members, especially tribal members involvement in promotion of ecotourism concept in Kerala is highly noticed (Prasrti,2017)

\section{Review of Literature}

The tribal peoples of Adilabad District of Andhra Pradesh are involved in activities of Vana Samrakshana Samithis'. Their activities support the forest protection and also get livelihood income for tribals. Majority of the forest dependent communities are tribal in the study area. After the formation of the Vana Samrakshana Samithi (VSS) the women members' involvement has increased and certain spices collected from forest being alone. The tribal members participation give more strength the concept of Participatory Forest Management (PFM) in the meaning of forest protection and management (Muthyalu,2013).

Ismaiel,Khalid and Mustafa (2017) the study stated the role of eco-tourism in sustainable forest management at Ajloun forest in Jordan. The sustainability, poverty alleviation and conservations are major challenging problems faced by the developing countries. How to be connected the local community and local resources for the development. Eco-tourism management plays a prominent role the development of the local community. Tourism industry is the one of the best industry for the development of the forest management and livelihood mission for the local community. Their multiple capabilities and resources should use in the eco-tourism concept.

\section{OBJECTIVE OF THE STUDY Overall Objective}

To analyse the role and functions of Vana Samrakshana Samithi (VSS) among the tribal members at Vazhachal eco-tourism destination.

\section{Specific Objectives}

1) To examine the demographic features of the tribals in Vazhachal eco-tourism area.

2) To study the housing conditions of tribals in Vazhachal eco-tourism area.

3) To evaluate the household items of tribals in Vazhachal eco-tourism area.

4) To analyse the environmental impact of Vana Samrakshana Samithi (VSS) among the tribals in Vazhachal eco-tourism area.

\section{STATEMENT OF THE PROBLEM}

Forest protection and management are the key points of the every forest policy drafts. The 1988 forest policy gave a new vision to the forest protection and management in the role of Community Forest Management (CFM). Forest protection and livelihood mission for the forest dependent communities are major highlight of the Participatory Forest Management 
(PFM). The tribal communities are engaged in collection of Non-Timber Forest Produce (NTFP). The activities of Vana Samrakshana Samithis'(VSSs) are praiseworthy and they have involved in forest protection and promotion of eco-tourism in Kerala. The forest dependent communities survival is mainly depended on collection of Non Timber Forest Produce (NTFP). The demands for the Non-Timber Forest Produce items are high. The Study (Santhosh,2014) stated that the Eco-development projects in Periyar Tiger Reserve, more positive impacted in conservation and livelihood income among the tribal forest dependents'. The eco-tourism activities supported the local tribal people, decreased the dependency on forest and reported that the illegal activities in forest also turned down. They have given more commitment on forest protection. The better output of the Ecodevelopment project is communities and conservation properly goes together.

The Vana Samrakshana Samithi (VSS) plays a major vital role in promoting eco-tourism and in forest protection. The tribal VSS members engaged in various supporting activities on forest conservation activities. The study (Meera,2004) mentioned that, the VSS members engaged in building primary infrastructural facilities at eco-tourism destinations in Trivandrum District. The VSS members supported the Kerala forest Department officials by various VSS programmes as non-plastic campaign mission, tourist guides and guards, eco-tourism destinations beautification programmes and forest produce harvesting. The forest dependent communities get livelihood income in one hand and another hand promotion of local development. VSS members help the police department by road safety awareness programmes, waste clear management programmes and tourists supporting programmes (Times of India,2018). The proper policies and programme implementations have resulted in new beginnings. The VSS activities have supported enhancement of forest protection and eco-tourism management. The paper analyses the role of Vana Samrakshana Samithi (VSS) tribal members in the promotion of forest protection, environmental protection and eco-tourism management at Vazhachal eco-tourism destination in Thrissur District of Kerala. The paper discusses the impact of Vana Samrakshana Samithi (VSS) activities among the tribal members and their areas on decreasing dependency on Forest, nonplastic area mission, forest protection attitude, ecotourism activities and decreasing illegal activities against forest after joining in VSS.

\section{SIGNIFICANCE OF THE STUDY}

Vana Samrakshana Samithi (VSS) activities have a great role in forest dependent communities, especially in tribals life. Their role and functions of Vana Samrakshana Samithis'(VSSs) are very supportive for tribals socially, economically and culturally. The VSSs have a perfect role in promoting eco-tourism especially in eco-tourism destinations. According to this study we can analyse that how far the VSS activities have supported the environmental protection, forest protection and eco-tourism concept in Vazhachal eco-tourism destination. The major highlight of the study is to analyse the environment impact of Vana Samrakshana Samithi (VSS) activities among the tribals of Vazhachal eco-tourism destination.

\section{Location and Coverage}

The Study covers the Vazhachal tribal colony in Athirappilly eco-tourism area at Thrissur District of Kerala. Athirappilly-Vazhachal waterfalls are very famous eco-tourism destinations in Kerala. Athirappilly -Vazhachal areas includes 13 tribal colonies and 11 Vana Samrakshana Samithis (VSSs). Among the 13 tribal colonies Vazhachal tribal colony is selected for the study and among the 11 Vana Samrakshana Samithis (VSSs) Vazhachal Vana Samrakshana Samithi (VSS) is selected for the study. The total population of the Vazhachal tribal colony is 202 members. The males are 99 and females are 103 .

\section{METHODOLOGY OF THE STUDY}

Primary data and secondary data were used for the study. The total sample size is 100 tribal respondents. Among the 100 tribal respondents, 50 are male respondents and 50 are female respondents. Simple random method is used for the study. The primary data were collected by using a structured questionnaire to study the demographic features, housing conditions, acquiring household items and environmental impact on tribal members. The secondary data collected from Vazhachal Forest Department, Tribal Development office (Chalakudy), Vazhachal Vana Samrakshana Samithi office and Charpa forest Range office. Percentage method is used for the interpretation of demographic features, house conditions, household items and environmental trainability among the respondents. Environmental impact on respondents through Vana Samrakshana Samithi (VSS) is tested through chi-square test of goodness-of-fit. 
ISSN (Online): 2455-3662

EPRA International Journal of Multidisciplinary Research (IJMR) - Peer Reviewed Journal

Volume: 6 | Issue: 10 | October 2020 || Journal DOI: 10.36713/epra2013 || SJIF Impact Factor: 7.032 ||ISI Value: 1.188

Table. 1

Age-Wise Classification of the Respondents

\begin{tabular}{|c|c|c|c|c|c|c|}
\hline Age & $\begin{array}{c}\text { Male } \\
\text { Respondents }\end{array}$ & $\mathbf{\%}$ & $\begin{array}{c}\text { Female } \\
\text { Respondents }\end{array}$ & $\mathbf{\%}$ & Total & \% \\
\hline $\mathbf{1 8 - 3 0}$ & 14 & 28.0 & 13 & 26.0 & 27 & 27.0 \\
\hline $\mathbf{3 1 - 4 0}$ & 16 & 32.0 & 15 & 30.0 & 31 & 31.0 \\
\hline $\mathbf{4 1 - 5 0}$ & 12 & 24.0 & 14 & 28.0 & 26 & 26.0 \\
\hline $\mathbf{5 1 - 6 0}$ & 6 & 12.0 & 7 & 14.0 & 13 & 13.0 \\
\hline $\mathbf{6 1}$ and Above & 2 & 4.0 & 1 & 2.0 & 3 & 3.0 \\
\hline Total & $\mathbf{5 0}$ & $\mathbf{1 0 0 . 0}$ & $\mathbf{5 0}$ & $\mathbf{1 0 0 . 0}$ & $\mathbf{1 0 0}$ & $\mathbf{1 0 0 . 0}$ \\
\hline
\end{tabular}

Source: Primary Data (2019-20)

Table. 1 mentions the Age-Wise classification of the respondents. Among the 100 respondents, 16 male respondents (32.0 percentages) and 15 female respondents (31.0 percentages) are in 31-40 age group and it is the highest participation age group in the study.

Table. 2

Marital Status of the Respondents

\begin{tabular}{|c|c|c|c|c|c|c|}
\hline $\begin{array}{c}\text { Marital } \\
\text { Status }\end{array}$ & $\begin{array}{c}\text { Male } \\
\text { Respondents }\end{array}$ & $\mathbf{\%}$ & $\begin{array}{c}\text { Female } \\
\text { Respondents }\end{array}$ & $\mathbf{\%}$ & Total & \% \\
\hline Married & 35 & 70.0 & 36 & 72.0 & 71 & 71.0 \\
\hline Unmarried & 14 & 28.0 & 10 & 20.0 & 24 & 24.0 \\
\hline Separated & 1 & 2.0 & 0 & 0.0 & 1 & 1.0 \\
\hline Widowed & 0 & 0.0 & 2 & 4.0 & 2 & 2.0 \\
\hline Abandoned & 0 & 0.0 & 2 & 4.0 & 2 & 2.0 \\
\hline Total & $\mathbf{5 0}$ & $\mathbf{1 0 0 . 0}$ & $\mathbf{5 0}$ & $\mathbf{1 0 0 . 0}$ & $\mathbf{1 0 0}$ & $\mathbf{1 0 0 . 0}$ \\
\hline
\end{tabular}

Source: Primary Data (2019-20)

Table. 2 show the marital status of the respondents. Majority of the respondents are married. About 70.0 percentages (35 male respondents) and 72. 0 percentages (36 female respondents) are married.

Table.3

Educational Background of the Respondents

\begin{tabular}{|c|c|c|c|c|c|c|}
\hline Education & $\begin{array}{c}\text { Male } \\
\text { Respondents }\end{array}$ & $\mathbf{\%}$ & Female Respondents & $\mathbf{\%}$ & Total & $\mathbf{\%}$ \\
\hline Illiterate & 10 & 20.0 & 8 & 16.0 & 18 & 18.0 \\
\hline Primary Education & 23 & 46.0 & 19 & 38.0 & 42 & 42.0 \\
\hline Secondary Education & 12 & 24.0 & 13 & 26.0 & 25 & 25.0 \\
\hline Higher Secondary Education & 5 & 10.0 & 7 & 14.0 & 12 & 12.0 \\
\hline Graduation & 0 & 0.0 & 2 & 4.0 & 2 & 2.0 \\
\hline Post-Graduation & 0 & 0.0 & 1 & 2.0 & 1 & 1.0 \\
\hline Total & $\mathbf{5 0}$ & $\mathbf{1 0 0 . 0}$ & $\mathbf{5 0}$ & $\mathbf{1 0 0 . 0}$ & $\mathbf{1 0 0}$ & $\mathbf{1 0 0 . 0}$ \\
\hline
\end{tabular}

Table. 3 indicates the educational background of the respondents. Among the 100 respondents, 23 male respondent (46.0 percentages) and 19 female respondents (38.0 percentages) are attained primary education. About 20 percentages (10 male respondents) and 16.0 percentages ( 8 female respondents) are illiterate. About 4 percentages ( 2 female respondents) and 2.0 percentages ( 1 female respondent) have secured Graduation and Post-Graduation respectively. 
Table.4

Housing Conditions of the Respondents

\begin{tabular}{|c|l|c|c|c|c|c|c|}
\hline $\begin{array}{c}\text { Housing } \\
\text { Condition }\end{array}$ & Structure & Male & \% & Female & \% & Total & \% \\
\hline Roofing & Concreted & 48 & 96.0 & 50 & 100.0 & 98 & 98.0 \\
\hline Wall & Brick & 20 & 40.0 & 27 & 54.0 & 47 & 47.0 \\
\cline { 2 - 8 } & Hallow Brick & 23 & 46.0 & 19 & 38.0 & 42 & 42.0 \\
\hline Flooring & Concreted & 43 & 86.0 & 42 & 84.0 & 85 & 85.0 \\
\hline $\begin{array}{c}\text { Energy } \\
\text { (Cooking) }\end{array}$ & Gas & 41 & 82.0 & 42 & 84.0 & 83 & 83.0 \\
\hline $\begin{array}{c}\text { Drinking } \\
\text { Water }\end{array}$ & $\begin{array}{c}\text { Connection } \\
\text { (Jalanidhi) }\end{array}$ & 45 & 90.0 & 46 & 92.0 & 91 & 91.0 \\
\hline $\begin{array}{c}\text { Electrified } \\
\text { House }\end{array}$ & Electrified & 50 & 100.0 & 50 & 100.0 & 100 & 100.0 \\
\hline $\begin{array}{c}\text { Toilet } \\
\text { Facility }\end{array}$ & Toilet & 40 & 80.0 & 39 & 78.0 & 79 & 79.0 \\
\hline
\end{tabular}

Source: Primary Data (2019-20)

Table.4 mentions the housing conditions of the respondents. Majority of the respondents' houses roofing are concreted. About 96.0 percentages (48 male respondents) and 100.0 percentages (50 female respondents) are lived in concreted houses. Among the 100 respondents, 20 male respondents (40.0 percentages) and 27 female respondents (54.0 percentages) houses built with brick wall. About 46 percentages (23 male respondents) and 38.0 percentages (19 female respondents), houses are constructed with Hallow Brick. Among the 100 respondents, 43 male respondents (86.0 percentages) and 42 female respondents $(84.0$ percentages $)$ respondents' have concreted flooring houses. About 82.0 percentages (41 male respondents) and 84.0 percentages (42 female respondents) are using LPG energy for cooking. Among the 100 respondents, 45 male respondents ( 90.0 percentages) and 46 female respondents ( 92.0 percentages) are using Jalanidhi pipe connection for drinking water. About 100.0 percentages (50 male and 50 female respondents) respondents' houses are electrified. Among the 100 respondents, 40 male respondents ( 80.0 percentages) and 39 female respondents (78.0 percentages) have toilet facility in their houses.

Table.5

Household Items of the Respondents

\begin{tabular}{|c|c|c|c|c|}
\hline Household Assets & $\begin{array}{c}\text { Male } \\
\text { Respondents }\end{array}$ & $\mathbf{\%}$ & $\begin{array}{c}\text { Female } \\
\text { Respondents }\end{array}$ & \% \\
\hline Table & 50 & 100.0 & 50 & 100.0 \\
\hline Chair & 50 & 100.0 & 50 & 700.0 \\
\hline Alamara & 38 & 76.0 & 39 & 100.0 \\
\hline Fan & 50 & 100.0 & 50 & 78.0 \\
\hline Television & 36 & 72.0 & 39 & 80.0 \\
\hline Mixi & 39 & 78.0 & 40 & \\
\hline
\end{tabular}


ISSN (Online): 2455-3662

EPRA International Journal of Multidisciplinary Research (IJMR) - Peer Reviewed Journal

Volume: 6 | Issue: 10 | October 2020 || Journal DOI: 10.36713/epra2013 || SJIF Impact Factor: 7.032 ||ISI Value: 1.188

\begin{tabular}{|c|c|c|c|c|}
\hline Iron Box & 40 & 80.0 & 41 & 84.0 \\
\hline Refrigerator & 3 & 6.0 & 43 & 8.0 \\
\hline Gas Stove & 42 & 84.0 & 23 & 46.0 \\
\hline Kerosene Stove & 25 & 50.0 & 43 & 86.0 \\
\hline Cooker & 40 & 80.0 & 50 & 100.0 \\
\hline Mobile Phone & 50 & 100.0 & 41 & 82.0 \\
\hline Smart Phone & 38 & 76.0 & 1 & 2.0 \\
\hline Computer & 1 & 2.0 & 43 & 86.0 \\
\hline Gold/Ornament & 11 & 22.0 & 23 & 46.0 \\
\hline Stitching Machine & 0.0 & 0.0 & 0 & 0.0 \\
\hline Two Wheeler & 3 & 6.0 & 0 & 0.0 \\
\hline Four Wheeler & 2 & 4.0 & 1 & 2.0 \\
\hline Buffalo & 0.0 & 0,0 & 3 & 6.0 \\
\hline Poultry Farming & 0.0 & 0.0 & & \\
\hline
\end{tabular}

Source: Primary Data (2019-20)

Table.5 mentions the household items of the respondents. . Among the 100 respondents, 50 male and 50 female respondents (100.0 percentages) are using mobile phone. About 76.0 percentages (38 male respondents) and 82.0 percentages (41 female respondents) are using smart phone. Among the 100 respondents, 36 male respondents ( 72.0 percentages) and 39 female respondents $(78.0$ percentages $)$ are having Television

Table.6

Environmental Impact Through Vana Samrakshana Samithi Among the Respondents

\begin{tabular}{|c|c|c|c|c|c|c|c|c|c|c|}
\hline \multirow[t]{2}{*}{ Variable } & \multicolumn{2}{|c|}{$\begin{array}{l}\text { Strongly } \\
\text { Disagree }\end{array}$} & \multicolumn{2}{|c|}{ Disagree } & \multicolumn{2}{|c|}{ Neutral } & \multicolumn{2}{|c|}{ Agree } & \multicolumn{2}{|c|}{$\begin{array}{c}\text { Strongly } \\
\text { Agree }\end{array}$} \\
\hline & $\mathbf{N}$ & $\%$ & $\mathbf{N}$ & $\%$ & $\mathbf{N}$ & $\%$ & $\mathbf{N}$ & $\%$ & $\mathbf{N}$ & $\%$ \\
\hline IDDF & 0 & 0.0 & 9 & 9.0 & 6 & 6.0 & 67 & 67.0 & 18 & 18.0 \\
\hline INPAM & 1 & 1.0 & 5 & 5.0 & 5 & 5.0 & 56 & 56.0 & 33 & 33.0 \\
\hline IFPA & 0 & 0.0 & 1 & 1.0 & 5 & 5.0 & 60 & 60.0 & 34 & 34.0 \\
\hline IETA & 2 & 2.0 & 9 & 9.0 & 7 & 7.0 & 58 & 58.0 & 24 & 24.0 \\
\hline IDIAF & 2 & 2.0 & 10 & 10.0 & 13 & 13.0 & 49 & 49.0 & 26 & 26.0 \\
\hline
\end{tabular}

Source: Primary Data (2019-20)

\begin{tabular}{|l|l|}
\hline IDDF & Improvement in decreasing dependency on Forest \\
\hline INPAM & Improvement in Non-Plastic Area Mission \\
\hline IFPA & Improvement in Forest Protection Attitude \\
\hline IETA & Improvement in Eco-Tourism Activities \\
\hline IDIAF & $\begin{array}{l}\text { Improvement in Decreasing illegal Activities against } \\
\text { Forest }\end{array}$ \\
\hline
\end{tabular}

Table.6 indicates the environmental impact through Vana Samrakshanan Samithi (VSS) among the respondents. Among the 100 respondents, 67 respondents agreed and 18 respondents strongly agreed that VSS activities, trainings and awareness programmes helped them in improving decreasing dependency on forest. About 56.0 percentages (56 respondents) agreed that there has an improvement in promotion of Non-Plastic mission campaign after joining in VSS. Among the 100 respondents, 34 respondents strongly agreed and 60 respondents agreed that the forest protection attitude improved among the 
ISSN (Online): 2455-3662

EPRA International Journal of Multidisciplinary Research (IJMR) - Peer Reviewed Journal

Volume: 6 | Issue: 10 | October 2020 || Journal DOI: 10.36713/epra2013 || SJIF Impact Factor: 7.032 ||ISI Value: 1.188

respondents after joining in VSS. About 58 percentages (58 respondents) agreed that, VSS members have been involved promotion of eco-tourism activities after joining in VSS. Among the 100 respondents, 26 respondents strongly agreed and 49 respondents agreed that there has an improvement in decreasing illegal activities against forest after joining in VSS.

Figure.1

Environmental Impact Through Vana Samrakshana Samithi Among the Respondents

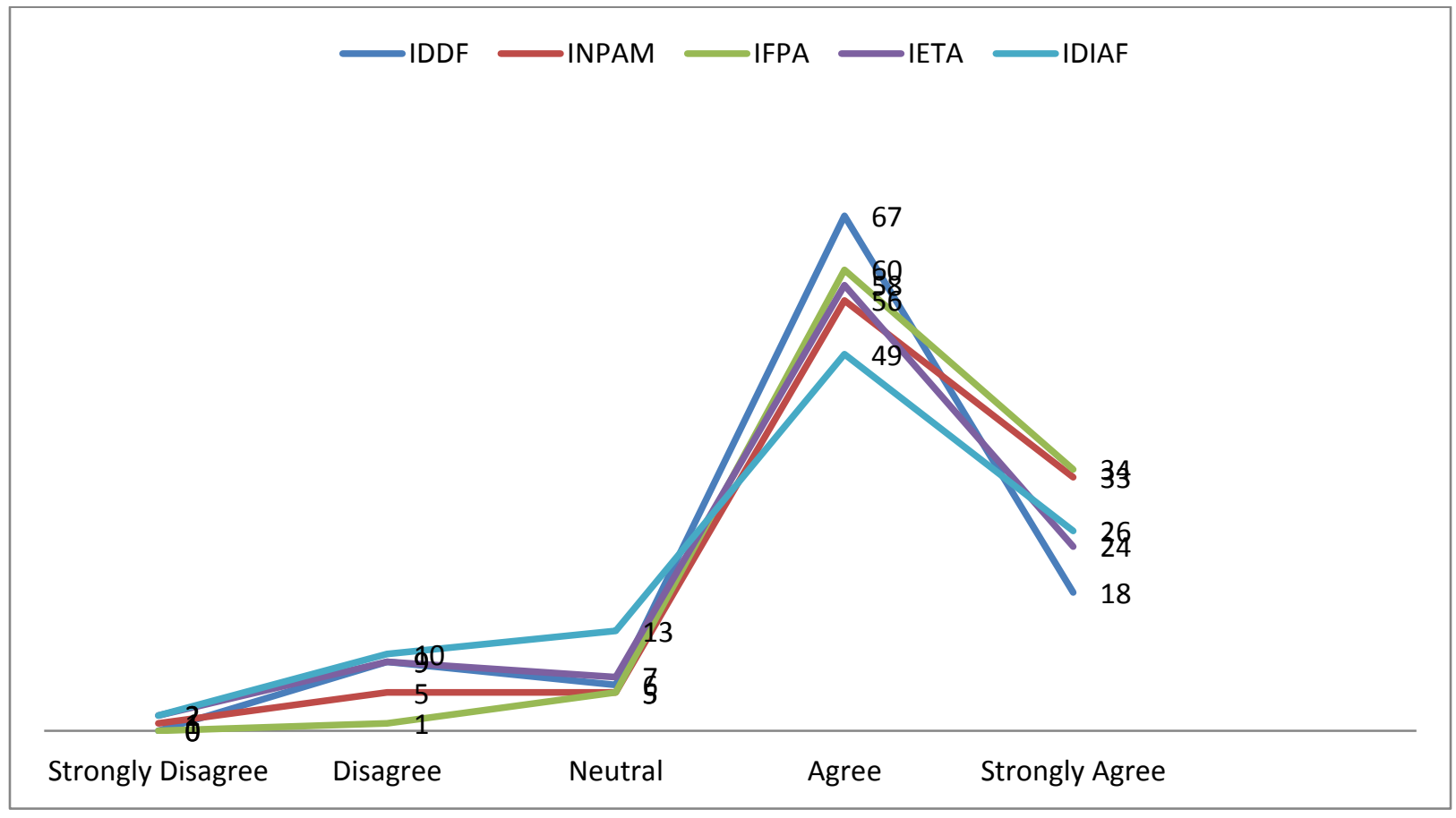

Source: Primary Data (2019-20)

Operational Definition: Environmental Impact through Vana Samarakshana Samithi (VSS) Membership includes Improvement in Decreasing Dependency on Forest (IDDF), Improvement in NonPlastic Area Mission (INPAM), Improvement in Forest Protection Attitude (IFPA), Improvement in Eco-
Tourism Activities (IETA) and Improvement in Decreasing Illegal Activities against Forest( IDIAF).

H0: $\quad$ There is no significant level of difference in environmental impact among the respondents after joining in Vana Samrakshana Samithi (VSS).

Table.7

Comparing sample based on the levels of agreement of Social Environmental Impact through VSS

\begin{tabular}{|c|c|c|c|c|c|}
\hline Variable & Agree & Neutral & Disagree & $0^{2}$ & Sig. \\
\hline IDDF & 85 & 6 & 9 & 120.26 & .000 \\
\hline INPAM & 89 & 5 & 6 & 139.46 & .000 \\
\hline IFPA & 94 & 5 & 1 & 165.86 & .000 \\
\hline IETA & 82 & 7 & 11 & 106.82 & .000 \\
\hline IDIAF & 75 & 13 & 12 & 78.14 & .000 \\
\hline
\end{tabular}


Table.7 indicates that the summary of chi-square test of goodness-of-fit presented indicate that responses of the sample on IDDF, INPAM, IFPA, IETA and IDIAF are significantly different, $\square^{2}=120.26,139.46,165.86$, 106.82 and $78.14, p<.01$. Further, responses indicate that majority of the sample agreed on the improvement in IDDF, INPAM, IFPA, IETA and IDIAF $(\mathrm{N}=$ $85,89,94,82$ and 75$) .12 \%$ and $11 \%$ of the sample disagreed on the improvement in IDIAF and IETA respectively. Together, sample perceived the Vana Samrakshana Samithi (VSS) programmes are effective on environmental empowerment among the respondents. Therefore the hypothesis 'There is no significant level of difference in environmental impact among the respondents after joining in Vana Samrakshana Samithi (VSS)' is rejected whereas considering (a) Improvement in decreasing dependency on Forest (IDDF), (b) Improvement in Non-Plastic area Mission (INPAM), (c) Improvement in Forest protection Attitude (IFPA), (d) Improvement in EcoTourism Activities (IETA) and (e) Improvement in Decreasing illegal Activities against Forest( IDIAF).

\section{MAJOR FINDINGS OF THE STUDY}

The highest age group participation is 31-40 age group in this study. Majority of the male and female respondents (71 respondents) are married. Among the 100 respondents, 44 respondents have attained primary education. Only 7 males and 8 females are illiterate. About 98.0 percentages (98 respondents) respondents' have concreted house roofing. Out of 100 respondents, 47 and 42 respondents houses built with respectively bricks and hollow bricks. About 85 percentages (85 respondents) respondents' houses have concreted flooring houses. Majority of the respondents (83 respondents) are using LPG energy for cooking. Among the 100 respondents, 91 respondents are depending Jalanidhi pipe water connection for source of drinking water. Among the 100 respondents 10 male respondents and 11 female respondents do not have toilet facility in their houses.

Among 100 respondents, 67 respondents agreed and 18 respondents strongly agreed that the Vana Samrakshana Samithi (VSS) helped them in improving in decreasing dependency on forest. Out of 100 respondents, 49 respondents agreed and 26 respondents strongly agreed that the Vana Samrakshana Samithi (VSS) helped them in improving in decreasing illegal activities against forest. After the formation of Vana Samrakshana Samithi (VSS) in Vazhachal the tribal respondents get income through the VSS activities. Availability of income makes them confident in their life and they give up the dependency on forest and illegal activities against the forest. Out of 100 respondents, 56 respondents agreed and 33 respondents strongly agreed that the Vana Samrakshana Samithi (VSS) activities helped them in improving in nonplastic mission concept. The VSS members are more caution on non-plastic mission and one of their activity is that daily they clean the Vazhachal eco-tourist areas and strictly warn the tourists, do not throw the plastic on road sides and tourism areas. Out of 100 respondents, 60 respondents agreed and 34 respondents strongly agreed that the Vana Samrakshana Samithi (VSS) activities helped them in improving in forest protection attitude. . Among the 100 respondents, 49 respondents agreed and 26 respondents strongly agreed that the Vana Samrakshana Samithi (VSS) activities helped them in improving in eco-tourism activities. VSS activities, campaigns and trainings have supported the tribals to educate themselves and make an interest among them to protect the forest and the promotion of the eco-tourism concept.

\section{CONCLUSION}

The forest dependent communities have great role in protection of forest and promotion of ecotourism concept. Vana Samrakshana Samithi (VSS) structure is one of the best channels for forest protection and promotion of the eco-tourism concept with the support of local community. Tribal communities are the major forest dependent communities and their life and breath are surrounded to forest. The forest dependent communities get income through various programmes of Vana Samrakshana Samithi (VSS). When they get income and employment through Vana Samrakshana Samithi (VSS), they are very happy and they decrease dependency on forest and illegal activities against forest The major highlights of the Vana Samrakshana Samithi (VSS) is that their activities always hold on eco-tourism promotion and follows strict measures protection eco-tourism concept. Non-Plastic area mission is being successfully maintained with the support of Vana Samrakshana Samithi (VSS) activities. The trainings of the Vana Samrakshana Samithi teach the forest protection attitude and importance of the non-plastic mission. This is not only in Vazhachal eco-tourism area but also in entire Kerala. The Vana Samrakshana Samithi (VSS) has been giving more importance to promoting ecotourism concept among the tourist and also in their locality. The environmental protection through the Vana Samrakshana Samithi (VSS) trainings are highly commendable. After the involvement of Vana Samrakshana Samithi (VSS) the environmental empowerment among the tribals is successfully continuing. The forest protection, and eco-tourism activities are strictly monitored by the Vana Samrakshana Samithi (VSS) with the support of Kerala Forest Department. 
REFERENCE

1. Anitha, V.,\& Muraleedharan,P. K. (2006). “ Economic Valuation of Ecotourism Development of Recreational Site in Natural Forest of Southern Western Ghats". KFRI Project, KFRI/387/03, Kerala Forest Research Institute.

2. Ecotourism in Kerala, (1999), Department of Public Relations, Govt. of Kerala

3. Ismaiel, Abuamoud, Khalid., M. Al-khalid.,\& Mustafa, Al-Shadiefat. (2017). "Supporting Ecotourism Through Sustainable Forest Management". Dirast: Human and Social Science, 43(2), 2016-33.

4. KSPB Report. (2014). "Entrepreneurialism and Environmental Sustainability Kerala”. Perspective Plan-2030, State Planning Board Report, Government Press Thiruvanathapuram, pp.212213.

5. Meera, Ranjith. (2004). “To Examine the Potential and Scope of Eco-Tourism in Kerala with Special Focus on Tourists to Ecotourism Destinations in Trivandrum". Journal of Tourism \& Hospitality, Hospit 9.433,DOI 10.35248/2167-0269.20.09.433.

6. M. Muthyalu,M.(2013). "Impact of Vana Samrakshana Samithi (VSS) in forest Development Activities with special Reference to Non-Timber Forest Produce (NTFP)- An Empirical Analysis. Journal of Business Management \& Social Science Research, ISSN No 2319-5614, Volume 2, No 2, February.

7. Periyar Tiger Reserve. (2001). "The Wild \& The Wonderful : Wildlife sanctuaries and National parks of Kerala", Department of Tourism, Government of Kerala

8. Prasriti, Srivatava. (2017). "Role of Tribal Vana Samrakshana Samithi Members in Building Environmental Protection and Eco-Tourism in Vazhachal Eco-Tourist Area in Thrissur District of Kerala”. 2 Times of India, 5 September.

9. Santhosh, P. Thampi. (2015). "Eco-Tourism in Kerala, India Lesson from the Eco Development Project in Periyar Tiger Reserve". ECOCLUB.com, E Paper Series, Nr-13, June.

10. Sangchumnong, A. (2018). "Development of a sustainable tourist destination based on the creative economy: A case study of Klong Kone Mangrove Community, Thailand". Kasetsart Journal of Social Science, [Online:1st September 2019]. Available at: https://www.sciencedirect.com/science/article/pii/S 2452315117304162.

11. The International Ecotourism Society, USA, email: ecomail@ecotourism.org

12. Times of India. (2018). "Vana Samrakshana Samithi to Help Police Keep Ponmudi Road Safe".April 15.

13. Tourism Statistics, Department of Tourism. (2002). Government of Kerala. 